\title{
ALDH4A1 wt Allele
}

National Cancer Institute

\section{Source}

National Cancer Institute. ALDH4A1 wt Allele. NCI Thesaurus. Code C152044.

Human ALDH4A1 wild-type allele is located in the vicinity of 1 p36.13 and is approximately $31 \mathrm{~kb}$ in length. This allele, which encodes delta-1-pyrroline-5-carboxylate dehydrogenase protein, mitochondrial, plays a role in glutamate synthesis. Mutation of the gene is associated with type II hyperprolinemia. 